\title{
Breast cancer and metabolic syndrome linked through the plasminogen activator inhibitor-1 cycle
}

\author{
Lea M. Beaulieu ${ }^{1}$, Brandi R. Whitley ${ }^{1}$, Theodore F. Wiesner ${ }^{2,{ }^{*}}$, Sophie M. Rehault ${ }^{1}$, Diane \\ Palmieri $^{1, \dagger}$, Abdel G. Elkahloun ${ }^{3, \ddagger}$, and Frank C. Church ${ }^{1,{ }^{* \star}}$ \\ ${ }^{1}$ Departments of Pathology and Laboratory Medicine, University of North Carolina at Chapel Hill, \\ School of Medicine, Chapel Hill, NC 27599-7035.
}

2Departments of Biology, University of North Carolina at Chapel Hill, Chapel Hill, NC 27599-7035.

${ }^{3} \mathrm{NHGRI-NIH} \mathrm{Genome} \mathrm{Technology} \mathrm{Branch,} \mathrm{National} \mathrm{Institute} \mathrm{of} \mathrm{Health,} \mathrm{Bethesda,} \mathrm{MD} 20892$.

\section{Summary}

\begin{abstract}
Plasminogen activator inhibitor-1 (PAI-1) is a physiological inhibitor of urokinase (uPA), a serine protease known to promote cell migration and invasion. Intuitively, increased levels of PAI-1 should be beneficial in down-regulating uPA activity, particularly in cancer. By contrast, in vivo, increased levels of PAI-1 are associated with a poor prognosis in breast cancer. This phenomenon is termed the "PAI-1 paradox". Many factors are responsible for the upregulation of PAI-1 in the tumor micro-environment. We hypothesize that there is a breast cancer predisposition to a more aggressive stage when PAI-1 is upregulated as a consequence of Metabolic Syndrome (MetS). MetS exerts a detrimental effect on the breast tumor microenvironment that supports cancer invasion. People with MetS have an increased risk of coronary heart disease, stroke, peripheral vascular disease and hyper-insulinemia. Recently, MetS has also been identified as a risk factor for breast cancer. We hypothesize the existence of the "PAI-1 cycle". Sustained by MetS, adipocytokines alter PAI-1 expression to promote angio-genesis, tumor-cell migration and procoagulant micro-particle formation from endothelial cells, which generates thrombin and further propagates PAI-1 synthesis. All of these factors culminate in a chemotherapy-resistant breast tumor microenvironment. The PAI-1 cycle may partly explain the PAI-1 paradox. In this hypothesis paper, we will discuss further how MetS upregulates PAI-1 and how an increased level of PAI-1 can be linked to a poor prognosis.
\end{abstract}

\footnotetext{
(C) 2007 Wiley Periodicals, Inc.

${ }^{* *}$ Correspondence to: Frank C. Church, Division of Hematology-Oncology/Department of Medicine, 932 Mary Ellen Jones Bldg, Campus Box 7035, University of North Carolina-Chapel Hill, Chapel Hill, NC 27599-7035. fchurch@email.unc.edu.

*Current address: Cato Research Inc., Durham, NC 27713.

$\dagger$ Current address: INRA, UR83 Recherches Avicoles F-37380 Nouzilly, France.

† Current address: Women’s Cancer Section, Lab of Molecular Pharmacology, National Cancer Institute, Bathesda, MD 20892. Funding for L.M.B. includes the following in part through an NRSANIH predoctoral fellowship (F31 NS054590) and was previously supported by the UNC-CH Integrative Vascular Biology Program (NIH T32 HL69768) and the Susan G. Komen Breast Cancer Foundation (BCTR0503475); Funding agency: NIEHS; Grant number: 5T32-ES-07017 (to B.R.W. and D.P. ); Funding agency: UNCCH Office of Undergraduate Research; Smallwood Undergraduate Research Fellowship (to T.F.W.); Funding agency: Association pour la Recherche sur le Cancer (ARC) (to S.M.R.); Funding agency: Susan G. Komen Breast Cancer Foundation to F.C.C.; Grant numbers: BCTR0503475, BCTR45206.
} 


\section{Introduction}

Western diet, Metabolic Syndrome (MetS) and breast cancer

"When diet is wrong medicine is of no use. When diet is correct medicine is of no need." Ancient Ayurvedic Proverb

Breast cancer is the second leading cause of cancer deaths among women in the United States. It is predicted that there will be more than 178,000 new cases of invasive breast cancer and more than 40,000 estimated deaths from breast cancer in 2007. ${ }^{(1)}$ The lifetime probability of a woman developing breast cancer is 1 in $7 .^{(2)}$ The duration of exposure to estrogen is a major risk factor for breast cancer. ${ }^{(2)}$ Modifiable risk factors for breast cancer include obesity, excessive alcohol use and physical inactivity. ${ }^{(2)}$ Invasion and metastasis are significant hindrances to the effective treatment of women with breast cancer. ${ }^{(3,4)}$ Despite advances in detection and therapy, many women will return with distant metastases and eventually succumb to their disease. Understanding the mechanisms that promote or permit invasion is crucial to the development of effective therapies.

Obesity and the resulting associated metabolic pathologies, now termed Metabolic Syndrome (MetS), affect more than 50\% of adults in the United States. MetS is a group of metabolic risk factors, including central obesity, dyslipidemia, hyperinsulinemia, hypertension and prothrombotic/proinflammatory states. ${ }^{(5,6)}$ MetS increases the risk of coronary heart disease, stroke, peripheral vascular disease and hyperinsulinemia. ${ }^{(7,8)}$ There is growing epidemiological data to suggest a correlation between high-fat consumption from a Western diet and breast cancer in humans. ${ }^{(9-11)}$ Recently, it was shown that obesity and weight gain are associated with increased breast cancer recurrence and cancer mortality. ${ }^{(12-14)}$

In the breast, adipocytes are responsible for the synthesis of adipocytokines, potent cellular modulators upregulated during MetS. ${ }^{(7,8,15-19)}$ Besides adipocytes, there are vascular endothelial cells and stromal fibroblasts that can be regulated by adipocytokines. ${ }^{(20)}$ In addition, a prominent feature of MetS is the upregulation of the serine protease inhibitor (serpin), plasminogen activator inhibitor-1 (PAI-1; systematic name, SERPINE1). ${ }^{(20-23)}$ PAI-1 is a physiological inhibitor of urokinase-type plasminogen activator (uPA), a serine pro-tease involved in the promotion of cellular de-adhesion, migration/invasion and activation of plasmin from plasminogen. ${ }^{(24-27)}$ uPA is upregulated in breast cancer as it progresses to a metastatic disease. Increased levels of the protease are associated with a poor prognosis. ${ }^{(28)}$

Instinctively, one would predict that increased expression of PAI-1 might be beneficial in breast cancer, since it potently inhibits uPA proteolytic activity. In vitro, PAI-1 has been shown to inhibit the effects of uPA in cancer. ${ }^{(24-27)}$ However, several clinical studies have found that increased PAI-1 expression in breast cancer is associated with a grim prognosis. ${ }^{(3)}$ In the following sections, we present a hypothesis to possibly explain the relationship of MetS to breast cancer, via a link with PAI-1. We hypothesize that MetS and adipocytokines alter the microenvironment surrounding the tumor cell by changing the 
expression of various factors, including PAI-1, that promote breast cancer cell migration and invasion (Figs 1 and 2).

\section{Plasminogen activator system and breast cancer}

The plasminogen activator (PA) system plays an important role in promoting tumor cell invasion. ${ }^{(24-27)} \mathrm{uPA}$ is a serine protease involved in many cellular processes including motility, activation of plasminogen to plasmin and activating pro-matrix metalloproteases (MMPs). While bound to the urokinase receptor (uPAR), uPA activates the zymogen plasminogen to the serine protease plasmin at the cell surface. Plasmin activates MMPs and degrades the surrounding extracellular matrix (ECM). ${ }^{(24-27)}$ Serpins control proteolytic activity during normal and pathological processes. ${ }^{(29,30)}$ There are four serpins that regulate the serine proteases of the PA system, PAI-1, plasminogen activator inhibitor-2, plasminogen activator inhibitor-3 (also known as protein $\mathrm{C}$ inhibitor) and a-plasmin inhibitor. An imbalance in the ratio of protease to the inhibitor allows for increased degradation of the ECM and increased invasion of tumor cells, which explains why many components of the PA system are associated with poor prognosis in several types of cancer. $^{(24-27)}$

There is an inherent balance among uPA, uPAR and PAI-1 to regulate focal ECM proteolysis and invasion. ${ }^{(31)}$ However, the known biochemical function of PAI-1 contradicts its pathological function in cancer. An increased level of PAI-1 would be expected to inhibit uPA generation of plasmin, protecting the ECM from proteolysis and thus inhibiting invasion. By contrast, high PAI-1 levels correlate with a poor prognosis and reduced survival in many cancers including breast cancer. ${ }^{(3)}$ Analyses of pooled data from 18 separate studies showed unequivocally that high levels of PAI-1 and uPA in the tumor are associated with an increase in relapse and metastasis, and a decrease in survival, indicative of a poor prognosis in primary breast cancer. ${ }^{(3)}$ Furthermore, a prospective randomized investigation found that the levels of PAI-1 and uPA in primary breast cancer are predictive of disease recurrence. ${ }^{(28)}$

PAI-1 is expressed in many cell types including endothelial cells, fibroblasts, adipocytes, smooth muscle cells, numerous tissue epithelial cells, keratinocytes, granulosa cells and platelets. PAI-1 is the primary inhibitor of the PA system targeting both uPA and tissue-type PA (tPA). PAI-1, in the presence of either VN or heparin, also inhibits the serine protease thrombin, although the importance of this inhibition reaction in cancer biology is not well understood. PAI-1 is found in trace levels in peripheral blood because it is a potent uPA and tPA inhibitor and its latent and protease-complexed forms are rapidly cleared. PAI-1 is conformationally unstable, rapidly decaying to an inactive form within 1 to 2 hours. ${ }^{(32)}$ Binding to VN will stabilize PAI-1 for 4 to 6 hours. ${ }^{33,34)}$ PAI-1 will rapidly inhibit uPA, which is bound to urokinase receptor (UPAR) on the cell surface. The PAI-1:uPA:uPAR ternary complex interacts with the low density lipoprotein receptor-related protein (LRP), which internalizes the quaternary complex. ${ }^{(35)} \mathrm{UPAR}$ and LRP will recycle to the cell surface while PAI-1 and UPA are degraded. ${ }^{(36)}$ 
The "PAI-1 paradox" exists because increased levels of PAI-1, which presumably would downregulate uPA activity, should be considered good for cancer. However, in vivo, PAI-1 is associated with a poor prognosis in breast cancer. An increase in PAI-1 levels in the breast tumor environment will affect cell adhesion, migration and invasion, apoptosis and proliferation, cell signaling and tumor angiogenesis via a mechanism that is partly independent of its inhibitory site. ${ }^{(24-27,37)}$ We suggest the concept that increased levels of PAI-1 involve both "traditional" and "non-traditional" roles for PAI-1 in cancer biology.

\section{The hypothesis: PAI-1 cycle}

\section{PAI-1 cycle links MetS with breast cancer}

We propose that PAI-1 is upregulated as a consequence of MetS. This increase in PAI-1 exerts a detrimental effect on breast tumor cells, adipocytes, stromal fibroblasts and vascular endothelial cells to promote tumor cell invasion. The "PAI-1 cycle" is sustained by MetS, resulting in the increased expression of PAI-1 in the tumor microenvironment (Fig. 1). This PAI-1 will advance numerous pathological processes of breast cancer (Figure 2). However, we do not presume that all people with MetS will be predisposed to breast cancer. Adipocytokines, whose production is promoted by MetS, will alter PAI-1 expression. ${ }^{(7,8,18,38-40)}$ The induction of insulin-resistance in adipocytes by MetS will also sustain PAI-1 expression. ${ }^{(41,42)}$ Increased levels of PAI-1 will support tumor angiogenesis, ${ }^{(4-45)}$ promote tumor cell adhesion/de-adhesion and activate signaling pathways to promote tumor cell invasion. ${ }^{(24-27,46,47)}$ PAI-1 will also promote the generation of pro-coagulant microparticles from endothelial cells. These microparticles can support the activation of prothrombin to thrombin. ${ }^{(48-50)}$ Thrombin facilitates tumor cell migration by activating protease-activated receptors to further promote PAI-1 synthesis. ${ }^{(51,52)}$ Additionally, fibrin produced near the tumor by thrombin will coat the tumor cells, disguising the tumor from the immune system. ${ }^{(53,54)} \mathrm{PAI}-1$ will also counter act apoptosis, ${ }^{(55,56)}$ which could increase breast cancer cell survival when treated with a chemotherapeutic drug. Ultimately, the PAI-1 cycle would provide a chemotherapy-resistant breast tumor microenvironment primed for invasion/metastasis ${ }^{(55-59)}$ (Figs 1,2). We will further discuss the various pathophysiological aspects of the PAI-1 cycle and its role in cancer.

\section{Tumor angiogenesis}

PAI-1 has been shown to be both pro-angiogenic and anti-angiogenic. PAI- $1^{-/-}$mice, described by Devy et al ${ }^{(60)}$ and McMahon et al, ${ }^{(61)}$ have a reduction in angiogenesis, up to $60 \%,{ }^{(61)}$ compared to wild-type mice. Addition of wild-type (wt)-PAI-1 at physiological concentrations, up to $1 \mathrm{nM}$, restores/increases angiogenesis up to 3 -fold, as seen in two different angiogenic assays, ${ }^{(60,61)}$ while wt-PAI-1 above 1 to $2 \mathrm{nM}$ reduces angiogenesis in these same assays. ${ }^{(60,61)}$

How PAI-1 affects angiogenesis is not fully understood. Adenoviral gene transfer of wildtype and mutant forms of PAI-1 that either bind ineffectively to vitronectin (VN) or are unable to inhibit the PA system show angiogenesis is promoted through PAI-1 inhibition of uPA and tPA. ${ }^{(60,62)} \mathrm{uPA}$ and tPA activate plasminogen to plasmin. Excessive plasmin 
activity could lead to vessel destabilization. ${ }^{(62)}$ Others have shown that the interaction of PAI-1 with the surrounding ECM is a key parameter affecting the progression of angiogenesis. In neuroblastoma tumors, PAI-1 co-expresses with integrins, specifically $a_{\mathrm{v}} \beta_{3}$, on endothelial cells. ${ }^{(63)}$ PAI-1 binds to VN and prevents VN-integrin cell interactions, resulting in endothelial cell migration towards fibronectin. ${ }^{(63)}$

\section{Cell adhesion and proliferation}

The PA system is involved in both promoting and preventing cell adhesion. Cells can bind VN through integrins, such as $\alpha_{v} \beta^{3}$ and uPAR. ${ }^{(64,65)}$ uPAR on the cell surface binds directly to $\mathrm{VN}^{(65,66)}$ and this interaction will upregulate integrin binding to the ECM. uPA bound to UPAR also promotes the interaction of UPAR to VN and strengthens cell adhesion to the ECM. ${ }^{(67,68)}$ Occupied uPAR will also associate with integrins to further strengthen the cell's adhesion to VN [reviewed in Refs 69,70].

PAI-1 inhibits PA-system-mediated cell adhesion by disrupting the interactions of uPAR and integrins with the ECM. ${ }^{(64,65,71)}$ PAI-1 competes with uPAR for VN binding. ${ }^{(65)}$ PAI-1 will lose the ability to bind to VN when it complexes with uPAR-bound uPA. ${ }^{65,72)}$ PAI-1 inhibition of uPA prevents the serpin from interacting with the cell and ECM, promoting cell adhesion to VN, fibronectin and laminin. ${ }^{(73)}$ By removing PAI-1 from VN, cell adhesion is promoted through integrin interaction with the ECM. PAI-1 inhibition of uPA can also promote cell de-adhesion. Internalization of the integrin:uPAR:uPA:PAI-1 complex by LRP removes key components needed to adhere the cell to the ECM. ${ }^{(74)}$

We have found that overexpressing wild-type PAI-1 (wt-PAI-1) in the MDA-MB-435 cells, a breast cancer cell line, decreased the rate of proliferation when compared to either parental cells or the inactive mutant P14 PAI-1-expressing MDA-MB-435 cells (P14 is T333R PAI-1). ${ }^{(73,75,76)}$ Anchorage-dependent colony-forming efficiency was used as a measure of cell proliferation. The wt-PAI-1-expressing MDA-MB-435 cells had a decreased ability to form colonies compared to the parental, Neomycin vector control and P14-PAI-1-expressing MDA-MB-435 cells (Table 1). Anchorage-independent proliferation, a hallmark of metastatic potential, had similar results. wt-PAI-1-expressing MDA-MB-435 cells had a reduced ability to form colonies in soft agar when compared with the other MDA-MB-435 cells (Table 1). Although PAI-1 has been associated with a negative prognosis in breast cancer, these results show it to be a negative regulator of proliferation of breast cancer cells in vitro.

A possible explanation for the decrease in proliferation by PAI-1 may be through an established function of the cell signaling protein, Akt. Akt is involved in cell survival and proliferation [reviewed in Ref. 77]. PAI-1 ${ }^{-/}$endothelial cells have an increased level of phosphorylated Akt and an increased rate of proliferation. ${ }^{(78)} \mathrm{wt}-\mathrm{PAI}-1$-expressing MDAMB-435 cells have less phosphorylated Akt compared to inactive P14-PAI-1expressing MDA-MB-435 cells, parental MDA-MB-435 cells and Neomycin vector control MDA-MB-435 cells (data not included). Our laboratory and others have recently shown that PAI-1 levels are increased in cells that have had the phosphatidylinositol 3-kinase/Akt-Akt signaling axis inhibited. ${ }^{(42,79)}$ Why a negative indicator of breast cancer survival slows 
down cell proliferation is not fully understood. It is possible that PAI-1 may serve in a protective role; thus, slowing tumor cell growth could permit more genetic alterations to occur advancing breast cancer to a metastatic stage.

\section{Cell migration and invasion}

All components of the PA system are involved in regulating cell migration and invasion. These interactions of the PA system can be complex, cell-type-specific and often context specific. uPA stimulates migration of breast cancer cells, dependent on UPAR ligation and subsequent activation of cell signaling pathways by integrins. ${ }^{(80,81)}$ There is a reduction in tumor cell migration and metastasis when uPA is inhibited by PAI-1. When UPA is overexpressed, altering the ratio of protease to inhibitor, cell migration in vitro is promoted. ${ }^{(82)}$

PAI-1 has been shown to promote cell migration. Chazaud et al ${ }^{(83)}$ showed PAI-1 attaches to cells through uPA:uPAR, which alters cell morphology and promotes breast cancer cell migration. This increase in migration can only occur when all of the components of the PA system are present. ${ }^{(83)} \mathrm{wt}-\mathrm{PAI}-1$-expressing MDA-MB-435 cells are shown to have significantly increased chemotaxis to $\mathrm{VN}$ and fibronectin compared to control cells. ${ }^{(73)}$ Alternatively, PAI-1 can support cell migration by preventing cell adhesion to VN. ${ }^{(67,84)}$ In smooth muscle cells, PAI-1 increases migration by binding to LRP, which results in morphology changes, cytoskeleton reorganization and alterations in signaling pathways. ${ }^{(85)}$

PAI-1 also inhibits tumor cell migration. ${ }^{(72,75,86-88)}$ HT1080 cells expressing wt-PAI-1 have reduced cell migration in vitro and do not form many lung metastases in vivo. ${ }^{(82)}$ The same is true in glioma cells expressing PAI-1 with a reduction in invasion in vitro compared to wild type. ${ }^{(84)}$ Overexpressing PAI-1 in breast and ovarian cancer cells reduces both cell migration and invasion, dependent on the active form of PAI-1. ${ }^{(75)}$ PAI-1 will complex with uPA and through the formation of a ternary complex with uPAR, will also bind LRP. This quaternary complex is internalized resulting in a loss of components of the PA system and reduction in cell migration. ${ }^{(88)}$ Treatment with either receptor-associated protein (RAP), a LRP-binding protein that competitively inhibits ligand binding, or LRP-blocking antibodies reverses these effects on migration. However, PAI-1-mediated inhibition of migration can also be independent of its uPA-inhibitory role. A mutant form of PAI-1 that is unable to inhibit uPA also prevented cell migration by disrupting the interactions of $\mathrm{VN}$ and integrins. ${ }^{(72)}$ Smooth muscle cell migration can also be inhibited in the presence of PAI-1 through the disruption of $\mathrm{VN}$ binding to the cell. ${ }^{(87)}$

\section{Apoptosis and the gene expression profile of PAl-1-expressing cells}

Components of the PA system may regulate apoptosis. PAI-1 has been shown to inhibit apoptosis when added exogenously to both normal and tumor cells, again, due to its inhibition of uPA. ${ }^{(55)}$ This fact alone might explain the PAI-1 paradox. Excess PAI-1 protects cancer cells from apoptosis. As a result, PAI-1 could promote the formation of a more aggressive tumor. A closer examination of PAI- $1^{0} \mathrm{~S}$ inhibition of apoptosis showed that PAI-1 inhibits caspase-3-mediated apoptosis in vascular smooth muscle cells. ${ }^{(56)}$ 
Slower proliferating cells tend to have a decreased sensitivity to chemotherapeutic agents. ${ }^{(89)}$ We believe that endogenously produced PAI-1 confers a "survival advantage" upon cancer cells. It has been shown that the disruption of the cytoskeleton with chemotherapeutic drugs will alter the balance of protease-to-protease inhibitor in favor of PAI-1. ${ }^{(90)}$ PAI-1 expression is affected by the perturbation of the actin cytoskeleton by cytochalasin D. ${ }^{(57,58)}$ Although multiple chemotherapeutic drugs are used to treat breast cancer, paclitaxel (Taxol) has shown efficacy in patients with drug resistance cancers, including breast cancer. ${ }^{(91)}$ In our studies with the PAI-1-expressing MDA-MB-435 cells, paclitaxel initially induces cell death in both wt-PAI-1-expressing and P14-PAI-1expressing MDA-MB-435 cells (data not shown). However, when the cells were allowed to recover for 48 hours after treatment in complete medium, wt-PAI-1-expressing MDAMB-435 cells had an increase in survival compared to P14-PAI-1-expressing MDA-MB-435 cells, although when plated onto either vitronectin or fibronectin surfaces the increase in survival between cell types was less different (data not included). These results imply that PAI-1 increases cell survival that depends on the integrity of the inhibitory site.

The upregulation of PAI-1 in a cancer cell is clearly conducive to promoting tumor cell progression to a malignant state. A cDNA microarray analysis was done on RNA extracted from the PAI-1-expressing MDA-MB-435 cells compared to the parental and vector control MDA-MB-435 cells. Of those genes, a list was generated of genes that were upregulated $\geq 2.5$ or downregulated $\searrow 0.5$ compared to the MDA-MB-435 Neo cells (Table 2). Of the 23 genes upregulated in the wt-PAI-1-expressing MDA-MB-435 cells, many are associated with adhesion, motility and angiogenesis, thereby bringing nutrients to the tumor and providing a means for metastasis to occur. PAI-1 expression reduces cell proliferation by both upregulating genes associated with senescence (G protein-coupled receptor 1) and downregulating genes associated with promoting proliferation. These results agree with what has been published about the effects of PAI-1 on cancer.

PAI-1 expression in the MDA-MB-435 cells increases the expression of genes that are typically upregulated in various cancers, including breast cancer (Table 2). ELAV results in unstable mRNA in breast cancer ${ }^{(92)}$ and eta polypeptide, a 14-3-3 protein involved in various signal transduction pathways, binds to gremlin 1 , which is upregulated in numerous cancers, including breast cancer. ${ }^{(93)}$

Two genes that were upregulated in the wt-PAI-1-expressing MDA-MB-435 cells would make the cells more responsive to stimuli produced by the MetS (Table 2). Protein phosphatase $2 \mathrm{C}$, magnesium-dependent, catalytic subunit is a mitochondrial enzyme regulated by insulin. ${ }^{(94)}$ Niemann-Pick disease, type $\mathrm{C} 1$ is a lysosomal membrane protein involved in cholesterol trafficking, ${ }^{(95)}$ and, most importantly, in drug resistance by its drug efflux and sequestration. ${ }^{(96)}$

The genes downregulated in the wt-PAI-1-expressing MDA-MB-435 cells were less numerous (Table 2). These genes are associated with proliferation, differentiation and adhesion. Apolipoprotein D regulates both proliferation ${ }^{(97)}$ and cell migration. ${ }^{(98)}$ Follistatin is typically downregulated in cancer and is an inhibitor of anti-proliferative pathways. ${ }^{\left({ }^{99}\right)} \mathrm{G}$ 
protein-coupled receptor 126 , which is associated with adhesion, ${ }^{(100)}$ is also downregulated by PAI-1 expression.

\section{Conclusion}

"What is food to one man may be fierce poison to others." Lucretius (99 B.C.-55

$\mathrm{BC})$.

Obesity is a worldwide problem that contributes to the risk and prognosis of many cancers, including breast cancer. With a high-caloric and high-fat Western diet, the resulting MetS will enhance the synthesis of PAI-1 and other components of the PA system in the tumor microenvironment. Adipocytokines (insulin, insulin-like growth factor 1, tumor necrosis factor-alpha, interleukin-6 and leptin/adiponectin) and other by-products of MetS (such as glucose and cholesterol) will alter PAI-1 expression not only in breast tissue adipocytes and in endothelial cells but also in breast cancer cells to potentially favor invasion and metastasis. The complex role and interaction between obesity and MetS linked to PAI-1 expression will clearly be studied for many years to come, as many study the pathological consequences of increased levels of PAI-1.

We hypothesize that increased expression of PAI-1 and other components of the plasminogen activator system (UPA and uPAR) confers a survival advantage upon breast cancer cells by decreasing sensitivity to chemotherapeutic agents, regulating adhesion, increasing tumor angiogenesis and increasing cell migration (Figs 1,2). As many researchers and clinicians have been and are still trying to fully understand the role of PAI-1 in cancer, the PAI-1 cycle hypothesis may further explain the paradox as to why a protease inhibitor of ECM degradation is detrimental for women with breast cancer (Fig. 2).

\section{Acknowledgments}

We thank Ms. Jessica Polka for her artistic interpretation of the PAI-1 cycle.

\section{Abbreviations}

$\begin{array}{ll}\text { ECM } & \text { extracellular matrix } \\ \text { LRP } & \text { lipoprotein receptor-related protein } \\ \text { MMP } & \text { matrix metalloprotease } \\ \text { MetS } & \text { Metabolic Syndrome } \\ \text { P14 T333R PAI-1 } & \text { breast cancer cell line, MDA-MB-435, expressing a mutant } \\ \text { MDA-MB-435 } & \text { PAI-1, which has a Thr replaced at position 333 with an Arg } \\ \text { PA } & \text { plasminogen activator } \\ \text { PAI-1 } & \text { plasminogen activator inhibitor-1 } \\ \text { PAI-1 } & \text { PAI-1 knockout } \\ \text { RAP } & \text { receptor-associated protein }\end{array}$




$\begin{array}{ll}\text { uPA } & \text { urokinase-type plasminogen activator } \\ \text { uPAR } & \text { uPA receptor } \\ \text { tPA } & \text { tissue-type plasminogen activator } \\ \text { VN } & \text { vitronectin } \\ \text { wt-PAI-1 } & \text { wild-type PAI-1 }\end{array}$

\section{References}

1. Jemal A, Siegel R, Ward E, Murray T, Xu J, Thun MJ. Cancer statistics, 2007. CA Cancer J Clin. 2007; 57:43-66. [PubMed: 17237035]

2. Smigal C, Jemal A, Ward E, Cokkinides V, Smith R, Howe HL, Thun M. Trends in breast cancer by race and ethnicity: update 2006. CA Cancer J Clin. 2006; 56:168-183. [PubMed: 16737949]

3. Look MP, van Putten WL, Duffy MJ, Harbeck N, Christensen IJ, et al. Pooled analysis of prognostic impact of urokinase-type plasminogen activator and its inhibitor PAI-1 in 8377 breast cancer patients. J Natl Cancer Inst. 2002; 94:116-128. [PubMed: 11792750]

4. Foekens JA, Peters HA, Look MP, Portengen H, Schmitt M, et al. The urokinase system of plasminogen activation and prognosis in 780 breast cancer patients. Cancer Research. 2000; 60:636-643. [PubMed: 10676647]

5. Eckel RH, Grundy SM, Zimmet PZ. The metabolic syndrome. Lancet. 2005; 365:1415-1428. [PubMed: 15836891]

6. Despres JP, Lemieux I. Abdominal obesity and metabolic syndrome. Nature. 2006; 444:881-887. [PubMed: 17167477]

7. Rose DP, Komninou D, Stephenson GD. Obesity, adipocytokines, and insulin resistance in breast cancer. Obes Rev. 2004; 5:153-165. [PubMed: 15245384]

8. Wolf I, Sadetzki S, Catane R, Karasik A, Kaufman B. Diabetes mellitus and breast cancer. Lancet Oncol. 2005; 6:103-111. [PubMed: 15683819]

9. Calle EE, Rodriguez C, Walker-Thurmond K, Thun MJ. Over-weight, obesity, and mortality from cancer in a prospectively studied cohort of U.S. adults. N Engl J Med. 2003; 348:1625-1638. [PubMed: 12711737]

10. Duncan AM. The role of nutrition in the prevention of breast cancer. AACN Clin Issues. 2004; 15:119-135. [PubMed: 14767370]

11. Bingham SA, Luben R, Welch A, Wareham N, Khaw KT, Day N. Are imprecise methods obscuring a relation between fat and breast cancer? Lancet. 2003; 362:212-214. [PubMed: 12885485]

12. Kroenke $\mathrm{CH}$, Chen WY, Rosner B, Holmes MD. Weight, weight gain, and survival after breast cancer diagnosis. J Clin Oncol. 2005; 23:1370-1378. [PubMed: 15684320]

13. Furberg AS, Jasienska G, Bjurstam N, Torjesen PA, Emaus A, et al. Metabolic and hormonal profiles: HDL cholesterol as a plausible biomarker of breast cancer risk. The Norwegian EBBA Study. Cancer Epidemiol Biomarkers Prev. 2005; 14:33-40. [PubMed: 15668473]

14. Furberg AS, Veierod MB, Wilsgaard T, Bernstein L, Thune I. Serum high-density lipoprotein cholesterol, metabolic profile, and breast cancer risk. J Natl Cancer Inst. 2004; 96:1152-1160. [PubMed: 15292387]

15. Atkinson SJ, English JL, Holway N, Murphy G. Cellular cholesterol regulates MT1 MMP dependent activation of MMP 2 via MEK-1 in HT1080 fibrosarcoma cells. FEBS Lett. 2004; 566:65-70. [PubMed: 15147870]

16. Bray GA. Medical consequences of obesity. J Clin Endocrinol Metab. 2004; 89:2583-2589. [PubMed: 15181027]

17. Hsueh WA, Lyon CJ, Quinones MJ. Insulin resistance and the endothelium. Am J Med. 2004; 117:109-117. [PubMed: 15234647] 
18. Miyoshi Y, Funahashi T, Kihara S, Taguchi T, Tamaki Y, et al. Association of serum adiponectin levels with breast cancer risk. Clin Cancer Res. 2003; 9:5699-5704. [PubMed: 14654554]

19. Zhuang L, Kim J, Adam RM, Solomon KR, Freeman MR. Cholesterol targeting alters lipid raft composition and cell survival in prostate cancer cells and xenografts. J Clin Invest. 2005; 115:959-968. [PubMed: 15776112]

20. Ronti T, Lupattelli G, Mannarino E. The endocrine function of adipose tissue: an update. Clin Endocrinol (Oxf). 2006; 64:355-365. [PubMed: 16584505]

21. Mertens I, Verrijken A, Michiels JJ, Van der Planken M, Ruige JB, Van Gaal LF. Among inflammation and coagulation markers, PAI-1 is a true component of the metabolic syndrome. Int J Obes (Lond). 2006

22. Griffiths SL, Grainger DJ. Proposal of a novel diabetogenic mechanism involving the serpin PAI-1. Bioessays. 2006; 28:629-641. [PubMed: 16700057]

23. Alessi MC, Juhan-Vague I. PAI-1 and the metabolic syndrome: links, causes, and consequences. Arterioscler Thromb Vasc Biol. 2006; 26:2200-2207. [PubMed: 16931789]

24. Stefansson S, Lawrence DA. Old dogs and new tricks: proteases, inhibitors, and cell migration. Sci STKE 189:pe24. 2003

25. Durand MK, Bodker JS, Christensen A, Dupont DM, Hansen M, et al. Plasminogen activator inhibitor-I and tumour growth, invasion, and metastasis. Thromb Haemost. 2004; 91:438-449. [PubMed: 14983218]

26. Dano K, Behrendt N, Hoyer-Hansen G, Johnsen M, Lund LR, et al. Plasminogen activation and cancer. Thromb Haemost. 2005; 93:676-681. [PubMed: 15841311]

27. Dellas C, Loskutoff DJ. Historical analysis of PAI-1 from its discovery to its potential role in cell motility and disease. Thromb Haemost. 2005; 93:631-640. [PubMed: 15841306]

28. Janicke F, Prechtl A, Thomssen C, Harbeck N, Meisner C, et al. Randomized adjuvant chemotherapy trial in high-risk, lymph node-negative breast cancer patients identified by urokinase-type plasminogen activator and plasminogen activator inhibitor type 1. J Natl Cancer Inst. 2001; 93:913-920. [PubMed: 11416112]

29. Law RH, Zhang Q, McGowan S, Buckle AM, Silverman GA, et al. An overview of the serpin superfamily. Genome Biol. 2006; 7:216. [PubMed: 16737556]

30. Silverman GA, Bird PI, Carrell RW, Church FC, Coughlin PB, et al. The serpins are an expanding superfamily of structurally similar but functionally diverse proteins: Evolution, mechanism of inhibition, novel functions, and a revised nomenclature. J Biol Chem. 2001; 276:33293-33296. [PubMed: 11435447]

31. Liu G, Shuman MA, Cohen RL. Co-expression of urokinase, urokinase receptor and PAI-1 is necessary for optimum invasiveness of cultured lung cancer cells. Int J Cancer. 1995; 60:501-506. [PubMed: 7829264]

32. Hekman CM, Loskutoff DJ. Endothelial cells produce a latent inhibitor of plasminogen activators that can be activated by denaturants. J Biol Chem. 1985; 260:11581-11587. [PubMed: 3930479]

33. Declerck PJ, De Mol M, Alessi MC, Baudner S, Paques EP, et al. Purification and characterization of a plasminogen activator inhibitor 1 binding protein from human plasma. Identification as a multimeric form of S protein (vitronectin). J Biol Chem. 1988; 263:15454-15461. [PubMed: 2459123]

34. Mimuro J, Sawdey M, Hattori M, Luskutoff DJ. cDNA for bovine type 1 plasminogen activator inhibitor (PAI-1). Nucleic Acids Res. 1989; 17:8872. [PubMed: 2587231]

35. Stefansson S, Muhammad S, Cheng XF, Battey FD, Strickland DK, Lawrence DA. Plasminogen activator inhibitor-1 contains a cryptic high affinity binding site for the low density lipoprotein receptor-related protein. J Biol Chem. 1998; 273:6358-6366. [PubMed: 9497365]

36. Nykjaer A, Conese M, Christensen EI, Olson D, Cremona O, et al. Recycling of the urokinase receptor upon internalization of the uPA:serpin complexes. Embo J. 1997; 16:2610-2620. [PubMed: 9184208]

37. DeClerck YA, Imren S. Protease inhibitors: Role and potential therapeutic use in human cancer. European J Cancer. 1994; 30A:2170-2180. [PubMed: 7857719]

38. Lyon CJ, Hsueh WA. Effect of plasminogen activator inhibitor-1 in diabetes mellitus and cardiovascular disease. Am J Med. 2003; 115:62S-68S. [PubMed: 14678868] 
39. Lee EA, Seo JY, Jiang Z, Yu MR, Kwon MK, et al. Reactive oxygen species mediate high glucose-induced plasminogen activator inhibitor-1 up-regulation in mesangial cells and in diabetic kidney. Kidney Int. 2005; 67:1762-1771. [PubMed: 15840023]

40. Ma LJ, Mao SL, Taylor KL, Kanjanabuch T, Guan Y, et al. Prevention of obesity and insulin resistance in mice lacking plasminogen activator inhibitor 1. Diabetes. 2004; 53:336-346. [PubMed: 14747283]

41. Lopez-Alemany R, Redondo JM, Nagamine Y, Munoz-Canoves P. Plasminogen activator inhibitor type-1 inhibits insulin signaling by competing with alphavbeta3 integrin for vitronectin binding. Eur J Biochem. 2003; 270:814-821. [PubMed: 12603314]

42. Venugopal J, Hanashiro K, Yang ZZ, Nagamine Y. Identification and modulation of a caveolaedependent signal pathway that regulates plasminogen activator inhibitor-1 in insulin-resistant adipocytes. Proc Natl Acad Sci USA. 2004; 101:17120-17125. [PubMed: 15569940]

43. Bajou K, Lewalle J, Martinez C, Soria C, Lu H, et al. Human breast adenocarcinoma cell lines promote angiogenesis by providing cells with uPA-PAI-1 and by enhancing their expression. Int $\mathrm{J}$ Cancer. 2002; 100:501-516. [PubMed: 12124797]

44. Isogai C, Laug WE, Shimada H, Declerck PJ, Stins MF, et al. Plasminogen activator inhibitor-1 promotes angiogenesis by stimulating endothelial cell migration toward fibronectin. Cancer Res. 2001; 61:5587-5594. [PubMed: 11454712]

45. Stefansson S, Petitclerc E, Wong MK, McMahon GA, Brooks PC, Lawrence DA. Inhibition of angiogenesis in vivo by plasminogen activator inhibitor-1. J Biol Chem. 2001; 276:8135-8141. [PubMed: 11083866]

46. Bajou K, Maillard C, Jost M, Lijnen RH, Gils A, Declerck P, Carmeliet P, Foidart JM, Noel A. Host-derived plasminogen activator inhibitor-1 (PAI-1) concentration is critical for in vivo tumoral angiogenesis and growth. Oncogene. 2004; 23:6986-6990. [PubMed: 15286708]

47. Binder BR, Christ G, Gruber F, Grubic N, Hufnagl P, et al. Plasminogen activator inhibitor 1: physiological and pathophysiological roles. News Physiol Sci. 2002; 17:56-61. [PubMed: 11909993]

48. Brodsky SV, Malinowski K, Golightly M, Jesty J, Goligorsky MS. Plasminogen activator inhibitor-1 promotes formation of endothelial microparticles with procoagulant potential. Circulation. 2002; 106:2372-2378. [PubMed: 12403669]

49. Brodsky SV, Zhang F, Nasjletti A, Goligorsky MS. Endothelium-derived microparticles impair endothelial function in vitro. Am J Physiol Heart Circ Physiol. 2004; 286:H1910-1915. [PubMed: 15072974]

50. Hewett PW, Murray C. Modulation of human endothelial cell procoagulant activity in tumour models in vitro. Int J Cancer. 1996; 66:784-789. [PubMed: 8647650]

51. Hertig A, Rondeau E. Role of the coagulation/fibrinolysis system in fibrin-associated glomerular injury. J Am Soc Nephrol. 2004; 15:844-853. [PubMed: 15034086]

52. Pontrelli P, Ranieri E, Ursi M, Ghosh-Choudhury G, Gesualdo L, et al. jun-N-terminal kinase regulates thrombin-induced PAI-1 gene expression in proximal tubular epithelial cells. Kidney Int. 2004; 65:2249-2261. [PubMed: 15149338]

53. Im JH, Fu W, Wang H, Bhatia SK, Hammer DA, et al. Coagulation facilitates tumor cell spreading in the pulmonary vasculature during early metastatic colony formation. Cancer Res. 2004; 64:8613-8619. [PubMed: 15574768]

54. Langer F, Amirkhosravi A, Ingersoll SB, Walker JM, Spath B, et al. Experimental metastasis and primary tumor growth in mice with hemophilia A. J Thromb Haemost. 2006; 4:1056-1062. [PubMed: 16689759]

55. Kwaan HC, Wang J, Svoboda K, Declerck PJ. Plasminogen activator inhibitor 1 may promote tumour growth through inhibition of apoptosis. Br J Cancer. 2000; 82:1702-1708. [PubMed: 10817507]

56. Chen Y, Kelm RJ Jr, Budd RC, Sobel BE, Schneider DJ. Inhibition of apoptosis and caspase-3 in vascular smooth muscle cells by plasminogen activator inhibitor type-1. J Cell Biochem. 2004; 92:178-188. [PubMed: 15095413] 
57. Hawks K, Higgins PJ. Cell shape-dependent pathway of plasminogen activator inhibitor type-1 gene expression requires cytoskeletal reorganization. J Cell Physiol. 1998; 176:293-302. [PubMed: 9648916]

58. Providence KM, Kutz SM, Higgins PJ. Perturbation of the actin cytoskeleton induces PAI-1 gene expression in cultured epithelial cells independent of substrate anchorage. Cell Motil Cytoskeleton. 1999; 42:218-229. [PubMed: 10098935]

59. Lademann U, Romer MU, Jensen PB, Hofland KF, Larsen L, et al. Malignant transformation of wild-type but not plasminogen activator inhibitor-1 gene-deficient fibroblasts decreases cellular sensitivity to chemotherapy-mediated apoptosis. Eur J Cancer. 2005; 41:1095-1100. [PubMed: 15862760]

60. Devy L, Blacher S, Grignet-Debrus C, Bajou K, Masson V, et al. The pro- or antiangiogenic effect of plasminogen activator inhibitor 1 is dose dependent. FASEB J. 2002; 16:147-154. [PubMed: 11818362]

61. McMahon GA, Petitclerc E, Stefansson S, Smith E, Wong MK, et al. Plasminogen activator inhibitor-1 regulates tumor growth and angiogenesis. J Biol Chem. 2001; 276:33964-33968. [PubMed: 11441025]

62. Bajou K, Masson V, Gerard RD, Schmitt PM, Albert V, et al. The plasminogen activator inhibitor PAI-1 controls in vivo tumor vascularization by interaction with proteases, not vitronectin. Implications for antiangiogenic strategies. J Cell Biol. 2001; 152:777-784. [PubMed: 11266468]

63. Isogai C, Laug WE, Shimada H, Declerck PJ, Stins MF, et al. Plasminogen activator inhibitor-1 promotes angiogenesis by stimulating endothelial cell migration toward fibronectin. Cancer Res. 2001; 61:5587-5594. [PubMed: 11454712]

64. Deng G, Curriden SA, Hu G, Czekay RP, Loskutoff DJ. Plasminogen activator inhibitor-1 regulates cell adhesion by binding to the somatomedin B domain of vitronectin. J Cell Physiol. 2001; 189:23-33. [PubMed: 11573201]

65. Deng G, Curriden SA, Wang S, Rosenberg S, Loskutoff DJ. Is plasminogen activator inhibitor-1 the molecular switch that governs urokinase receptor-mediated cell adhesion and release? J Cell Biol. 1996; 134:1563-1571. [PubMed: 8830783]

66. Wei Y, Waltz DA, Rao N, Drummond RJ, Rosenberg S, Chapman HA. Identification of the urokinase receptor as an adhesion receptor for vitronectin. J Biol Chem. 1994; 269:32380-32388. [PubMed: 7528215]

67. Waltz DA, Natkin LR, Fujita RM, Wei Y, Chapman HA. Plasmin and plasminogen activator inhibitor type 1 promote cellular motility by regulating the interaction between the urokinase receptor and vitronectin. J Clin Invest. 1997; 100:58-67. [PubMed: 9202057]

68. Wei Y, Lukashev M, Simon DI, Bodary SC, Rosenberg S, et al. Regulation of integrin function by the urokinase receptor. Science. 1996; 273:1551-1555. [PubMed: 8703217]

69. Chapman HA, Wei Y. Protease crosstalk with integrins: the urokinase receptor paradigm. Thromb Haemost. 2001; 86:124-129. [PubMed: 11486997]

70. Kjoller L. The urokinase plasminogen activator receptor in the regulation of the actin cytoskeleton and cell motility. Biol Chem. 2002; 383:5-19. [PubMed: 11928822]

71. Okumura Y, Kamikubo Y, Curriden SA, Wang J, Kiwada T, et al. Kinetic analysis of the interaction between vitronectin and the urokinase receptor. J Biol Chem. 2002; 277:9395-9404. [PubMed: 11773078]

72. Kjoller L, Kanse SM, Kirkegaard T, Rodenburg KW, Ronne E, et al. Plasminogen activator inhibitor-1 represses integrin- and vitronectin-mediated cell migration independently of its function as an inhibitor of plasminogen activation. Exp Cell Res. 1997; 232:420-429. [PubMed: 9168821]

73. Palmieri D, Lee J-W, Juliano RL, Church FC. Plasminogen Activator Inhibitor-1 and -3 Increase Cell Adhesion and Motility of MDAMB-435 Breast Cancer Cells. J Biol Chem. 2002; 277:4095040957. [PubMed: 12176977]

74. Czekay RP, Aertgeerts K, Curriden SA, Loskutoff DJ. Plasminogen activator inhibitor-1 detaches cells from extracellular matrices by inactivating integrins. J Cell Biol. 2003; 160:781-791. [PubMed: 12615913] 
75. Whitley BR, Palmieri D, Twerdi C, Church FC. Expression of active plasminogen activator inhibitor-1 regulates cell migration and invasion in breast and gynecological cancer cells. Exp Cell Res. 2004; 296:151-162. [PubMed: 15149846]

76. Whitley BR, Palmieri D, Church FC. Effect of plasminogen activator inhibitor (PAI)-1 and PAI-3 in MDA-MB-435 breast cell proliferation. FASEB J. 2001; 15:A251.

77. Nicholson KM, Anderson NG. The protein kinase B/Akt signalling pathway in human malignancy. Cell Signal. 2002; 14:381-395. [PubMed: 11882383]

78. Ploplis VA, Balsara R, Sandoval-Cooper MJ, Yin ZJ, Batten J, et al. Enhanced in vitro proliferation of aortic endothelial cells from plasminogen activator inhibitor-1-deficient mice. J Biol Chem. 2004; 279:6143-6151. [PubMed: 14625301]

79. Whitley BR, Beaulieu LM, Carter JC, Church FC. Phosphatidylinositol 3-kinase/Akt regulates the balance between plasminogen activator inhibitor-1 and urokinase to promote migration of SKOV-3 ovarian cancer cells. Gynecol Oncol. 2007; 104:470-479. [PubMed: 17070899]

80. Nguyen DHD, Catling AD, Webb DJ, Sankovic M, Walker LA, et al. Myosin light chain kinase functions downstream of Ras/ERK to promote migration of urokinase-type plasminogen activatorstimulated cells in an integrin-selective manner. The Journal of Cell Biology. 1999; 146:149-164. [PubMed: 10402467]

81. Nguyen DHD, Webb DJ, Catling AD, Song Q, Dhakephalkar A, et al. Urokinase-type plasminogen activator stimulates the Ras/extracellular signal-related kinase (ERK) signaling pathway and MCF-7 cell migration by a mechanism that requires focal adhesion kinase, Src, and Shc. The Journal of Biological Chemistry. 2000; 275:19382-19388. [PubMed: 10777511]

82. Praus M, Wauterickx K, Collen D, Gerard RD. Reduction of tumor cell migration and metastasis by adenoviral gene transfer of plasminogen activator inhibitors. Gene Therapy. 1999; 6:227-236. [PubMed: 10435107]

83. Chazaud B, Ricoux R, Christov C, Plonquet A, Gherardi RK, Barlovatz-Meimon G. Promigratory effect of plasminogen activator inhibitor-1 on invasive breast cancer cell populations. Am J Pathol. 2002; 160:237-246. [PubMed: 11786417]

84. Hjortland GO, Bjornland K, Pettersen S, Garman-Vik SS, Emilsen E, Nesland JM, Fodstad O, Engebraaten O. Modulation of glioma cell invasion and motility by adenoviral gene transfer of PAI-1. Clin Exp Metastasis. 2003; 20:301-309. [PubMed: 12856717]

85. Degryse B, Neels JG, Czekay R-P, Aertgeerts K, Kamikubo Y-i, Loskutoff DJ. The Low Density Lipoprotein Receptor-related Protein Is a Motogenic Receptor for Plasminogen Activator Inhibitor-1. J Biol Chem. 2004; 279:22595-22604. [PubMed: 15001579]

86. Praus M, Collen D, Gerard RD. Both u-PA inhibition and vitronectin binding by plasminogen activator inhibitor 1 regulate HT1080 fibrosarcoma cell metastasis. Int J Cancer. 2002; 102:584591. [PubMed: 12447999]

87. Stefansson S, Lawrence DA, Argraves WS. Plasminogen activator inhibitor-1 and vitronectin promote the cellular clearance of thrombin by low density lipoprotein receptor-related proteins 1 and 2. J Biol Chem. 1996; 271:8215-8220. [PubMed: 8626514]

88. Degryse B, Sier CF, Resnati M, Conese M, Blasi F. PAI-1 inhibits urokinase-induced chemotaxis by internalizing the urokinase receptor. FEBS Lett. 2001; 505:249-254. [PubMed: 11566185]

89. Huuhtanen RL, Wiklund TA, Blomqvist CP, Bohling TO, Virolainen MJ, et al. A high proliferation rate measured by cyclin A predicts a favourable chemotherapy response in soft tissue sarcoma patients. Br J Cancer. 1999; 81:1017-1021. [PubMed: 10576659]

90. Santell L, Marotti K, Bartfeld NS, Baynham P, Levin EG. Disruption of microtubules inhibits the stimulation of tissue plasminogen activator expression and promotes plasminogen activator inhibitor type 1 expression in human endothelial cells. Exp Cell Res. 1992; 201:358-365. [PubMed: 1639133]

91. Gogas H, Fountzilas G. The role of taxanes as a component of neoadjuvant chemotherapy for breast cancer. Ann Oncol. 2003; 14:667-674. [PubMed: 12702519]

92. Denkert C, Weichert W, Winzer KJ, Muller BM, Noske A, et al. Expression of the ELAV-like protein $\mathrm{HuR}$ is associated with higher tumor grade and increased cyclooxygenase- 2 expression in human breast carcinoma. Clin Cancer Res. 2004; 10:5580-5586. [PubMed: 15328200] 
93. Namkoong H, Shin SM, Kim HK, Ha SA, Cho GW, et al. The bone morphogenetic protein antagonist gremlin 1 is overexpressed in human cancers and interacts with YWHAH protein. BMC Cancer. 2006; 6:74. [PubMed: 16545136]

94. Piccinini M, Mostert M, Alberto G, Ramondetti C, Novi RF, et al. Down-regulation of pyruvate dehydrogenase phosphatase in obese subjects is a defect that signals insulin resistance. Obes Res. 2005; 13:678-686. [PubMed: 15897476]

95. Garver WS, Krishnan K, Gallagos JR, Michikawa M, Francis GA, Heidenreich RA. Niemann-Pick $\mathrm{C} 1$ protein regulates cholesterol transport to the trans-Golgi network and plasma membrane caveolae. J Lipid Res. 2002; 43:579-589. [PubMed: 11907140]

96. Gong Y, Duvvuri M, Duncan MB, Liu J, Krise JP. Niemann-Pick C1 protein facilitates the efflux of the anticancer drug daunorubicin from cells according to a novel vesicle-mediated pathway. $\mathrm{J}$ Pharmacol Exp Ther. 2006; 316:242-247. [PubMed: 16174794]

97. Sarjeant JM, Lawrie A, Kinnear C, Yablonsky S, Leung W, et al. Apolipoprotein D inhibits platelet-derived growth factor-BB-induced vascular smooth muscle cell proliferated by preventing translocation of phosphorylated extracellular signal regulated kinase $1 / 2$ to the nucleus. Arterioscler Thromb Vasc Biol. 2003; 23:2172-2177. [PubMed: 14551159]

98. Leung WC, Lawrie A, Demaries S, Massaeli H, Burry A, et al. Apolipoprotein D and plateletderived growth factor-BB synergism mediates vascular smooth muscle cell migration. Circ Res. 2004; 95:179-186. [PubMed: 15192024]

99. Bartholin L, Maguer-Satta V, Hayette S, Martel S, Gadoux M, et al. Transcription activation of FLRG and follistatin by activin A, through Smad proteins, participates in a negative feedback loop to modulate activin A function. Oncogene. 2002; 21:2227-2235. [PubMed: 11948405]

100. Stehlik C, Kroismayr R, Dorfleutner A, Binder BR, Lipp J. VIGR-a novel inducible adhesion family G-protein coupled receptor in endothelial cells. FEBS Lett. 2004; 569:149-155. [PubMed: 15225624] 
Endocrine changes as a consequence of obesity and the Metabolic Syndrome (a partial list includes): increase in leptin, insulin/IGF-1, and IL-6/TNF- $\alpha$, and a decrease in adiponectin

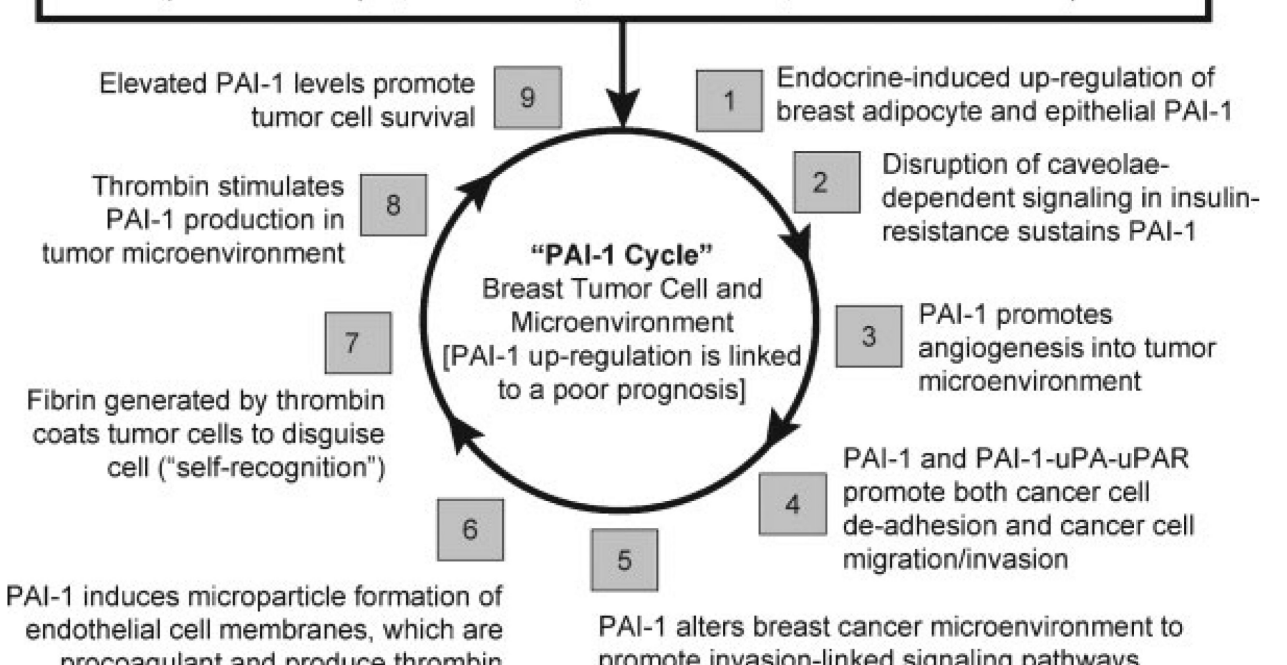
procoagulant and produce thrombin promote invasion-linked signaling pathways

Figure 1.

Breast cancer, MetS and the PAI-1 cycle. 


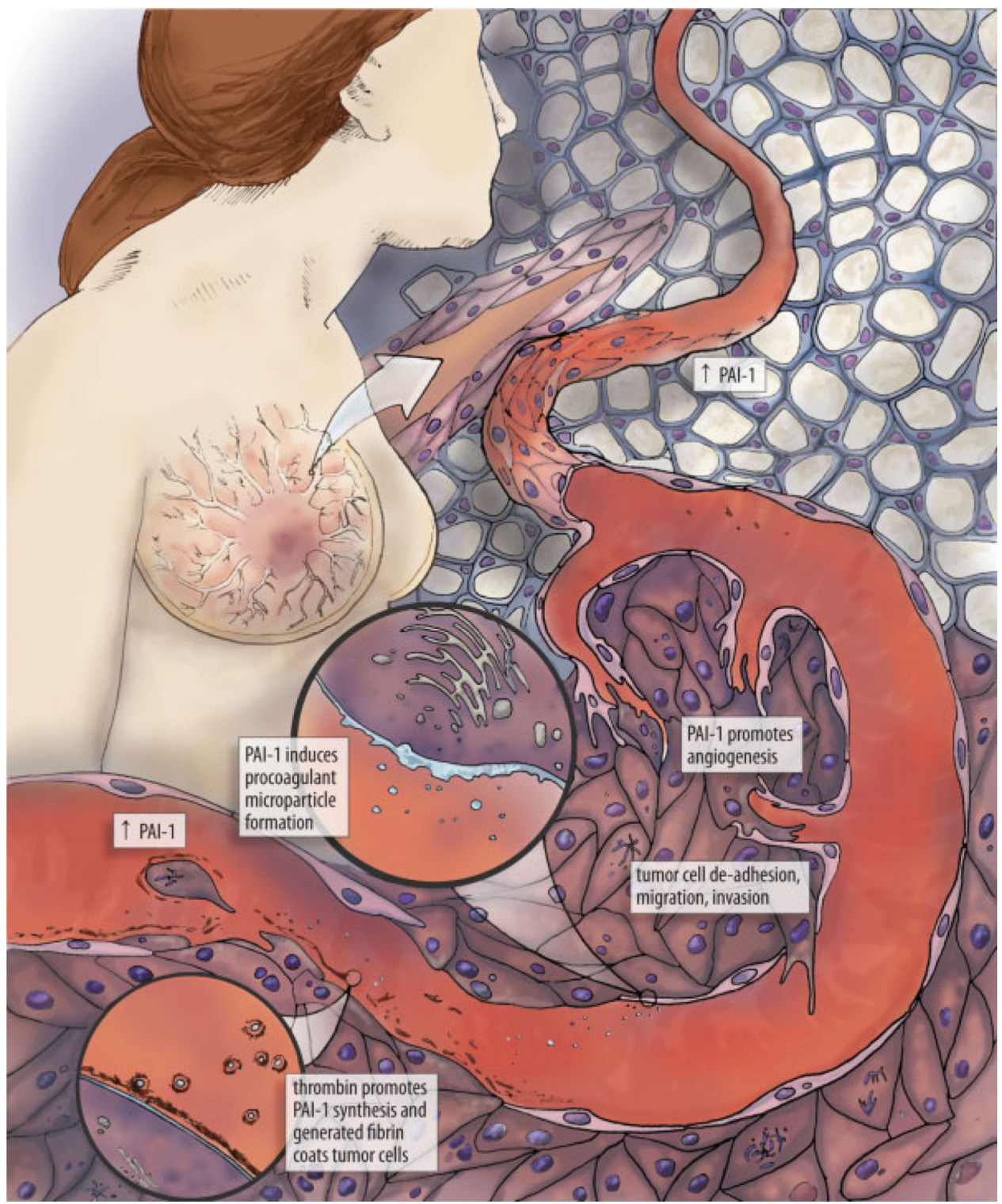

Figure 2.

Metastatic breast cancer and the PAI-1 cycle. Adipocytokines as a consequence of MetS will increase PAI-1 expression in breast adipocytes and surrounding tumor microenvironment. The increased levels of PAI-1 will support tumor angiogenesis, promote tumor cell adhesion/de-adhesion and activate signaling pathways to promote tumor cell invasion. PAI-1 will promote the generation of procoagulant microparticles from endothelial cells and thrombin will further promote PAI-1 synthesis. Fibrin will coat the tumor cells to help the tumor cells avoid immune surveillance. PAI-1 will also counteract apoptosis to provide a chemotherapy-resistant breast tumor microenvironment. Ultimately, the PAI-1 cycle will lead to sustained PAI-1 synthesis. 


\section{Table 1}

Stable Expression of wt-PAI-1 Decreases MDA-MB-435 Cell Proliferation ${ }^{a}$

\begin{tabular}{|lcc|}
\hline MDA-MB-435 Cell type & Anchorage-dependent proliferation (\% CFE) & Anchorage-independent proliferation (\% CFE) \\
\hline Parental & $100 \pm 5$ & $100 \pm 6$ \\
Neomycin vector control & $112 \pm 19$ & $90 \pm 8$ \\
wt-PAI-1-expressing & $53 \pm 23^{* *}$ & $58 \pm 14^{*}$ \\
& $121 \pm 9$ & $113 \pm 10$ \\
\hline
\end{tabular}

\footnotetext{
${ }^{a}$ MDA-MB-435 cells PAI-1-expressing [wildtype (wt) and inactive T333R (P14)] and control MDA-MB-435 cells were generated as described previously. ${ }^{73,75,76}$ For anchorage-dependent proliferation, cells were plated at 50 cells per $60 \mathrm{~mm}^{2}$ dish in $3 \mathrm{ml}$ growth media and grown for 14 days. Colonies were fixed in 3:1 methanol:acetic acid and stained with Giemsa. Colonies of $>50$ cells were counted and expressed as a $\%$ of the number of colonies in the parental MDA-MB-435 population to yield colony-forming efficiency (CFE). For anchorage-independent proliferation, soft agar assays were performed by plating 20,000 cells per $60 \mathrm{~mm}^{2}$ dish. Cells were suspended in a thin layer of $0.33 \%$ noble agar, which was overlaid on a $0.5 \%$ agar layer containing $10 \%$ FBS in $2 \times$ MEM. CFE's were assessed after 3 weeks by counting colonies with $>50$ cells. The data represent the average of 4 experiments performed in triplicate.

p $<0.05$

**

$\mathrm{p}<0.01$, compared with the parental MDA-MB- 435 cells.
} 


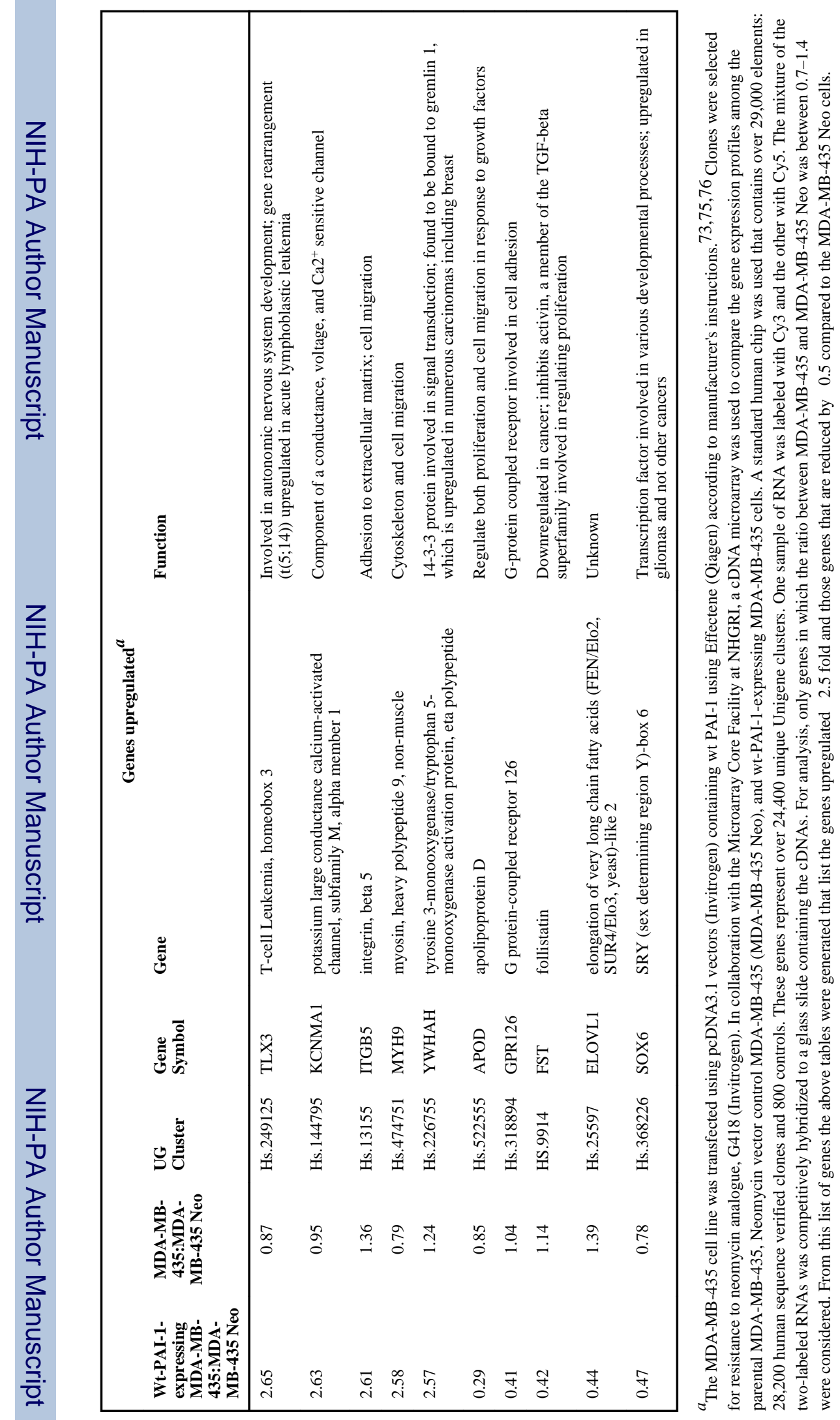

Bioessays. Author manuscript; available in PMC 2014 June 05. 